\title{
Model Persediaan Bahan Baku Multi Item dengan Mempertimbangkan Masa Kadaluwarsa, Unit Diskon dan Permintaan yang Tidak Konstan
}

\author{
Stanley Surya Jaya ${ }^{1}$, Tanti Octavia ${ }^{1 *}$, Gede Agus Widyadana ${ }^{1}$
}

\begin{abstract}
In the classical economic ordering quantity (EOQ) model, it was assumed that products have no expire date. However, in practices, some products such as food and milk, have exact expire date and some vendors tries to reduce their lost by introducing quantity unit discount. In this paper, we develop multi items inventory models by considering product expire date and quantity unit discount for stochastic demand environment. Due to complexity of the models, simulation and Genetic Algorithm are used to solve the models. We then verify the models using a numerical example and sensitivity analysis. The results from sensitivity analysis show that inventory cost and backorder cost have significant effect to ordering time.
\end{abstract}

Keywords: Expire date, unit discount, multi item, sthocastic demand.

\section{Pendahuluan}

Pengendalian persediaan bahan baku pada industri makanan atau produk-produk lain yang berkurang nilainya dengan berjalannya waktu serta memiliki waktu kadaluwarsa merupakan salah satu hal yang sangat penting untuk dilakukan. Hal ini dikarenakan perusahaan harus berusaha memenuhi permintaan konsumen yang bersifat tidak pasti dengan menggunakan bahan baku bersifat perishable (dapat mengalami penurunan nilai setelah waktu tertentu). Persediaan bahan baku yang berlebih pada kondisi ini dapat menimbulkan biaya kadaluwarsa yang besar. Kekurangan bahan baku dapat menimbulkan kerugian terjadinya kehilangan penjualan. Biaya yang ditimbulkan pada pengendalian persediaan (Elsayed et al. [3]) antara lain biaya pemesanan, biaya pembelian, biaya penyimpanan, dan biaya kekurangan.

Penelitian mengenai pengendalian persediaan untuk barang yang dapat kadaluwarsa telah dilakukan secara intensif oleh beberapa peneliti. Hsu [4] menyusun satu model persediaan untuk barang-barang yang berkurang kuantitas dan kualitas dengan cepat dengan berjalannya waktu hingga kemudian mencapai waktu kadaluwarsa. Barang-barang jenis ini diantaranya adalah bunga, buah-buahan, dan produk bahan makanan lainnya. Penelitian berikutnya berkembang dengan memperhatikan diskon harga, hal ini disebabkan oleh perlunya pemberian diskon harga untuk meningkatkan penjualan bagi barang yang akan kadaluwarsa. Dalam penelitiannya, Bramorski [1] menemukan bahwa 98\% respondennya selalu memperhatikan waktu kadaluwarsa

\footnotetext{
1 Fakultas Teknologi Industri, Program Studi Teknik Industri, Universitas Kristen Petra. Jl. Siwalankerto 121-131. Surabaya 60238. Email: tanti@petra.ac.id

* Penulis korespondensi
}

dari produk susu atau produk-produk lainnya yang memiliki waktu kadaluwarsa dan mereka melakukan pembelian dengan sistem LIFO (Last In First Out). Bramorski [1] juga menemukan bahwa dengan meningkatkan nilai diskon, responden memiki keinginan lebih untuk membeli produk yang lebih dekat dengan waktu kadaluwarsa. Oleh sebab itu faktor potongan harga (diskon) perlu dipertimbangkan dalam penyusunan satu kebijakan.

Beberapa bahan baku memiliki potongan harga atau diskon ketika dibeli dalam jumlah tertentu. Jumlah pembelian bahan baku yang semakin banyak dapat menimbulkan diskon yang semakin besar. Adanya diskon dapat menekan biaya produksi dan memberikan keuntungan bagi perusahaan. Permasalahan pembelian bahan baku untuk multi item dengan mempertimbangkan faktor diskon telah diteliti salah satunya oleh Djunaidi, et al. [2]. Permasalahan persediaan bahan baku dengan mempertimbangkan faktor kadaluwarsa maupun diskon telah banyak diteliti. Indrianti, et al. [6] melakukan penelitian pada permasalahan persediaan bahan baku yang mempertimbangkan faktor kadaluwarsa. Penelitian persediaan dengan mempertimbangkan faktor kadaluwarsa dan unit diskon juga dilakukan oleh Prasetyo et al. [10]. Kedua penelitian ini memberikan sebuah solusi matematis yang tidak melibatkan waktu kadaluwarsa. Panda, et al. [9] mengembangkan sebuah model matematis yang dapat memaksimalkan profit dengan mempertimbangkan pemberian potongan harga sebelum dan sesudah masa kadaluwarsa untuk satu jenis barang. Bramorski [1] mengembangkan model matematis untuk mengendalikan harga produk di supermarket dengan memperhatikan tingkat persediaan dan perkiraan waktu kadaluwarsa sebagai variable keputusan. Hsu et al. [5] mengembangkan model matematis untuk pengendalian persediaan dengan 
barang yang berkurang kuantitas dan kualitasnya dengan berjalannya waktu, tingkat permintaan musiman, kadaluwarsa dan backorder. Mereka mengembangkan dua model yaitu satu dengan mempertimbangkan diskon harga dan satu lagi tanpa mempertimbangkan diskon harga.

Masalah pengendalian ini akan semakin kompleks saat industri memerlukan bahan baku lebih dari satu jenis (multi item). Pemesanan bahan baku multi item yang tidak tepat berdampak pada tingkat persediaan perusahaan dan menimbulkan biaya tambahan ataupun keterlambatan produksi. Pengendalian bahan baku multi item yang baik dibutuhkan agar tingkat persediaan perusahaan berada dalam kondisi optimal. Persediaan untuk kasus multi item dengan pertimbangan prosentase kadaluwarsa dan unit diskon telah dikembangkan oleh Limansyah et al. [7]. Penelitian ini mengembangkan penelitian Limansyah et al. [7] dengan mempertimbangkan tingkat permintaan yang tidak konstan. Selain itu waktu kadaluwarsa barang yang sudah tertentu menjadi perhatian pada penelitian ini, disebabkan mayoritas barang memiliki waktu kadaluwarsa yang hampir pasti. Oleh sebab itu penelitian ini mencoba untuk membuat model yang sudah pernah dikembangkan sebelumnya menjadi lebih realistis. Pada penelitian ini akan dikembangkan model persediaan untuk multi item yang mempertimbangkan faktor kadaluwarsa dan unit diskon pada permasalahan demand yang tidak konstan.

Makalah ini akan dibagi menjadi empat bagian. Bagian pertama berisi pendahuluan, dan bagian kedua berisi model persediaan yang ada dan pengembangannya. Bagian ketiga dan terakhir merupakan hasil pembahasan dan simpulan dari penelitian yang telah dilakukan.

\section{Metode Penelitian}

\section{Pengembangan Model}

Notasi yang digunakan dalam model ini adalah:

Tc : total biaya persediaan

$P c$ : biaya pembelian

Oc : biaya pemesanan

$H c$ : biaya penyimpanan

Sc : biaya shortage

$T$ : lama periode

Ts : lama selang waktu siklus

$T k$ : lama waktu kadaluwarsa

Tl : lead time

$T 1$ : lama waktu efektif (selang antara barang hingga kadaluwarsa)

T2 : lama waktu tanpa adanya persediaan bahan

$T b$ : lama waktu hingga pesanan mulai menjadi backorder

D : permintaan tahunan
$Q \quad$ : jumlah pemesanan dalam satu siklus

$Q k \quad$ : jumlah kadaluwarsa dalam satu siklus

$M \quad$ : jumlah maksimum persediaan

$B \quad$ : jumlah persediaan pada titik pemesanan

$S \quad$ : biaya per pemesanan

$H \quad$ : fraksi biaya simpan

$\mathrm{Cb}$ : biaya backorder per unit per waktu

$\mathrm{Cl} \quad$ : biaya lost-sale per unit

$P \quad$ : harga beli

$J \quad$ : harga jual setelah kadaluwarsa

$T c^{*} \quad$ : total biaya persediaan minimum

$Q^{*} \quad$ : jumlah pembelian optimal

$T s^{*} \quad$ : lama selang waktu siklus optimal

$M^{*} \quad$ : jumlah maksimum persediaan optimal

$P 1_{i} \quad$ : harga beli pada price-break ke- $i$

$T c_{i}$ : total biaya persediaan dengan harga pricebreak ke-i

$T c_{i}{ }^{*} \quad$ : total biaya persediaan minimum dengan harga price-break ke-i $Q_{i}^{*}$

$T s_{i}^{*}$ : lama selang waktu siklus optimal dengan harga price-break ke- $i$

$M_{i}^{*} \quad$ : jumlah maksimum persediaan optimal dengan harga price-breakke-i

$P c_{j} \quad$ : biaya pembelian bahan $j$

$H c_{j} \quad$ : biaya penyimpanan bahan $j$

$\mathrm{Sc}_{j} \quad$ : biaya shortage bahan $j$

$P 2_{j} \quad$ : harga beli bahan $j$

$D_{j} \quad$ : permintaan tahunan bahan $j$

$Q \quad$ : jumlah pemesanan dalam satu siklus

$Q k \quad$ : jumlah kadaluwarsa dalam satu siklus

$M \quad$ : jumlah maksimum persediaan

$B$ : jumlah persediaan pada titik pemesanan

$S \quad$ : biaya per pemesanan

$H \quad$ : fraksi biaya simpan

$\mathrm{Cb}$ : biaya backorder per unit per waktu

$\mathrm{Cl} \quad$ : biaya lost-sale per unit

$P \quad$ : harga beli

$P_{j k} \quad$ : harga beli bahan $j$ untuk kombinasi pricebreak ke- $k$

$T c_{k} \quad$ : total biaya persediaan dengan harga kombinasi price-break ke- $k$

$T s_{k}{ }^{*}$ : lama selang waktu siklus optimal dengan harga kombinasi price-break ke- $k$

$Q_{j k}{ }^{*} \quad$ : jumlah pembelian optimal bahan $j$ dengan harga kombinasi price-break ke- $k$

$T c_{k}{ }^{*}$ : total biaya persediaan optimal dengan harga kombinasi price-break ke- $k$

$M_{j k}{ }^{*}$ : jumlah maksimum persediaan bahan $j$ dengan harga kombinasi price-break ke- $k$

$T b_{j}$ : lama waktu hingga pesanan mulai menjadi backorder bahan $j$

$Q_{t} \quad$ : jumlah pembelian pada siklus ke- $t$

$Q e_{t} \quad$ : jumlah sisa persediaan pada siklus ke- $t$

$C c_{j t}$ : biaya persediaan bahan $j$ pada siklus ke- $t$

$P c_{j t} \quad$ : biaya pembelian bahan $j$ pada siklus ke- $t$

$H c_{j t}$ : biaya penyimpanan bahan $j$ pada siklus ke- $t$

$S c_{j t} \quad$ : biaya shortage bahan j pada siklus ke- $t$

$T k_{j} \quad$ : lama waktu kadaluwarsa bahan $j$

$T 1_{j} \quad$ : lama waktu efektif (selang antara barang hingga kadaluwarsa) 
$D_{j t} \quad$ : permintaan bahan $j$ selama siklus ke- $t$

$Q_{j t} \quad$ : jumlah pemesanan dalam satu siklus bahan $j$ pada siklus ke- $t$

$Q k_{j t} \quad$ : jumlah kadaluwarsa dalam satu siklus bahan $j$ pada ke- $t$

$C b_{j} \quad$ : biaya backorder per unit per waktu bahan $j$

$C_{j} \quad$ : biaya lost-sale per unit bahan $j$

$J_{j} \quad$ : harga jual setelah kadaluwarsa bahan $j$

$i \quad$ : tingkat diskon dimana $i=1,2, \ldots, m$

$m \quad$ : jumlah tingkatan diskon

$j \quad: \quad$ jenis bahan dimana $j=1,2, \ldots, \mathrm{n}$

$n \quad:$ jumlah jenis barang

$k \quad$ : kombinasi interval price-break tiap jenis bahan dimana $k=1,2, \ldots ., o$

$o \quad$ : jumlah kombinasi interval price-break tiap jenis bahan

$t \quad: \quad$ siklus dimana $t=1,2, \ldots, p$

$p \quad:$ jumlah siklus

\section{Model EOQ dengan Mempertimbangkan Masa} Kadaluwarsa

EOQ (Economic Order Quantity) atau dapat disebut juga jumlah pemesanan yang ekonomis merupakan metode yang spesifik untuk menentukan persediaan barang. EOQ adalah jumlah yang memberikan keseimbangan antara biaya penyimpanan dan biaya pemesanan sehingga didapat biaya total minimum. Total biaya pada EOQ adalah (Russel et al. [11]):

$T c=P D+\frac{s}{T s}+\frac{D T s}{2} P H$

dimana

$T s^{*}=\sqrt{\frac{2 S}{D P H}}$

$Q^{*}=D T s^{*}$

Pada kasus persediaan yang mengijinkan kekurangan bahan. Komponen total biaya persediaan dipengaruhi pula oleh biaya backorder dan atau biaya lost-sales. Total biaya untuk EOQ untuk backorder yang diijinkan adalah (Muckstadt [8]):

$T c=P D+\frac{s}{T s}+\frac{D T s\left(\frac{C b}{P H+C b}\right)^{2}}{2} P H+\frac{D T s\left(\frac{P H}{P H+C b}\right)^{2}}{2} C b$

dimana

$\begin{aligned} M^{*} & =Q^{*} \frac{C b}{P H+C b} \\ T b & =T s \frac{M}{Q}\end{aligned}$

$T b=T s \frac{M}{Q}$

dan

$T s^{*}=\sqrt{\frac{2 S(P H+C b)}{D P H C b}}$

Gambar 1 menunjukkan dua model persediaan yang memperhatikan masa kadaluwarsa. Pada kasus dengan masa kadaluwarsa, bahan akan memiliki waktu efektif dari bahan datang hingga masa kadaluwarsa (T1) sebesar:

$T 1=T k-T l$
Apabila terjadi kadaluwarsa, maka terdapat selang waktu dimana tidak tersedia persediaan untuk memenuhi permintaan dimana nilainya adalah:

$T 2=T s-T 1$

Kasus lost-sales kadaluwarsa terjadi apabila $T s>T 1$, sementara pada kasus backorder, kadaluwarsa terjadi bila $T b>T 1$.

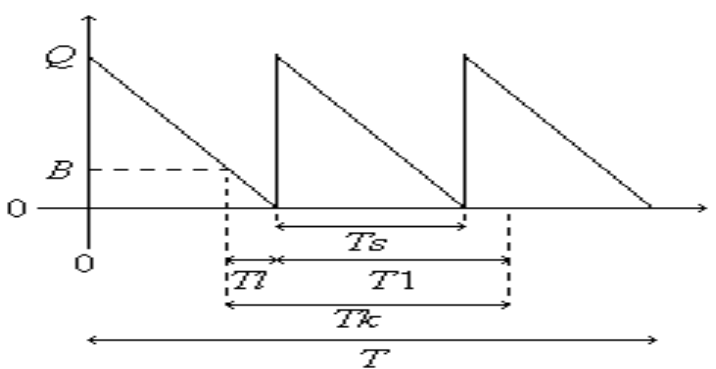

Gambar 1a. Model tanpa masa kadaluwarsa kasus lostsale

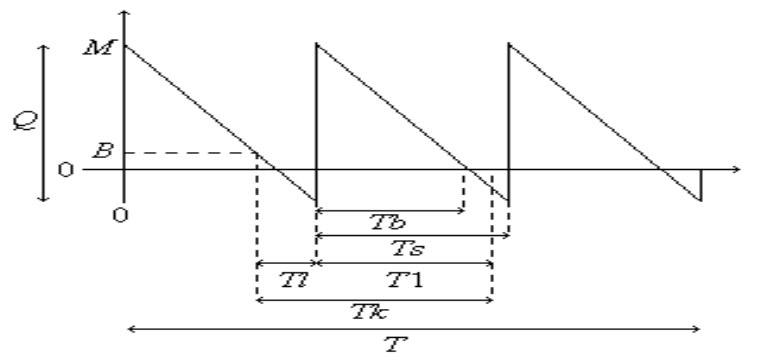

Gambar 1b. Model tanpa masa kadaluwarsa kasus backorder
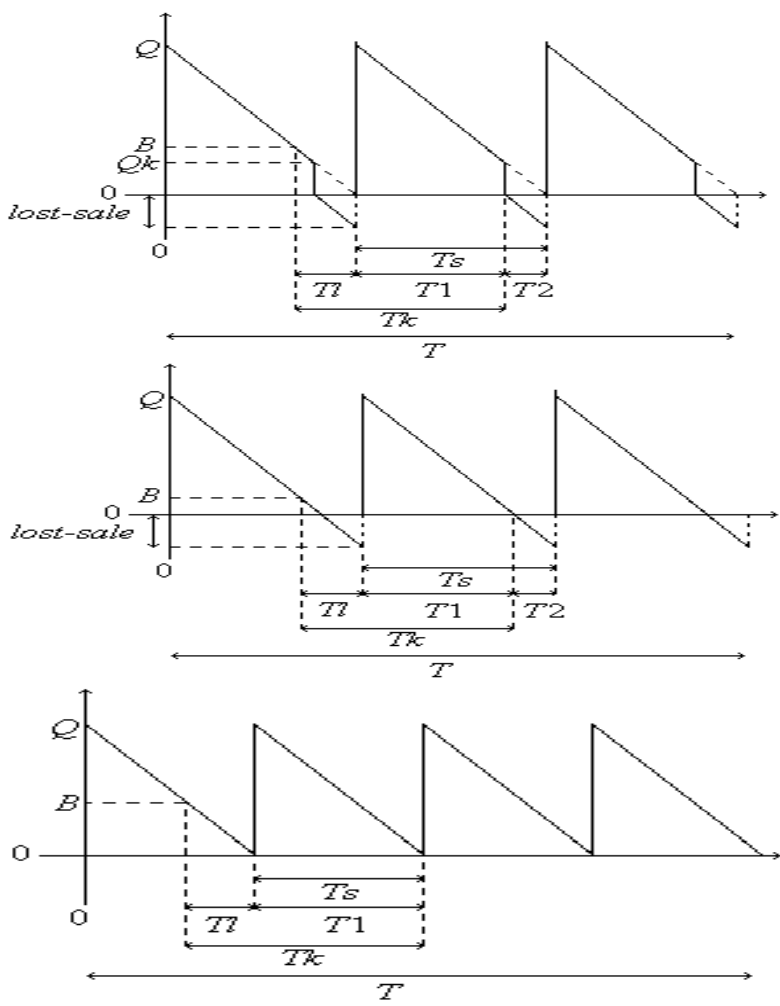

Gambar 2. Model persediaan dengan pertimbangan kadaluwarsa pada kasus lost-sale 
Gambar 2 menunjukkan bahwa pada kasus lostsales bahan lebih baik dibeli maksimum sesuai dengan jumlah permintaan selama waktu efektif $T 1$. Penyelesaian model dengan kasus lost-sales ini dilakukan dengan langkah-langkah sebagai berikut:

1. Menghitung nilai Ts dengan persamaan (2). Apabila nilai $T s$ lebih besar dari $T 1$, ubahlah $T s=T 1$ dan masukkan nilai $T s$ sebagai $T s^{*}$

2. Menghitung $T c^{*}$ dengan persamaan (1) dan $Q^{*}$ dengan persamaan (3)

Pada kasus backorder, besar maksimum persediaan (M) akan menghasilkan solusi yang lebih baik jika disesuaikan dengan jumlah permintaan selama waktu efektif T1 (lihat Gambar 3). Total biaya yang dikeluarkan pada kondisi ini sebagai berikut:

$T c=P D+\frac{S}{T s}+P H D \frac{(T k-T l)^{2}}{2 T s}+$
$\frac{C b D}{2}\left(T s-2(T k-T l)+\frac{(T k-T l)^{2}}{T s}\right)$

dimana

$T s^{*}=\sqrt{\frac{2\left(S+\frac{P H D}{2}(T k-T l)^{2}+\frac{C b D}{2}(T k-T l)^{2}\right)}{C b D}}$

Penyelesaian pada model persediaan dengan mempertimbangkan masa kadaluwarsa pada kasus backorder ini dapat dilakukan dengan tahapan berikut ini:

1. Menghitung nilai $T s$ dengan persamaan (7) dan $\mathrm{Tb}$ dengan menggunakan persamaan (5) dan (6). Apabila $T b<=T 1$, maka lanjutkan ke tahap 2 . Sebaliknya, lanjut ke tahap 3.

2. Memasukkan nilai $T s$ sebagai $T s^{*}$, kemudian hitung nilai $T c^{*}, Q^{*}, M^{*}$ dengan persamaan (4), (3), dan (5), secara berurutan.

Menghitung nilai $T s^{*}$ dengan persamaan (11). Apabila $T s^{*}<T 1$, maka $T s^{*}=T 1$. Menghitung nilai $T c^{*}$, $Q^{*}, M^{*}$ dengan persamaan (10), (3), dan (5), secara berurutan
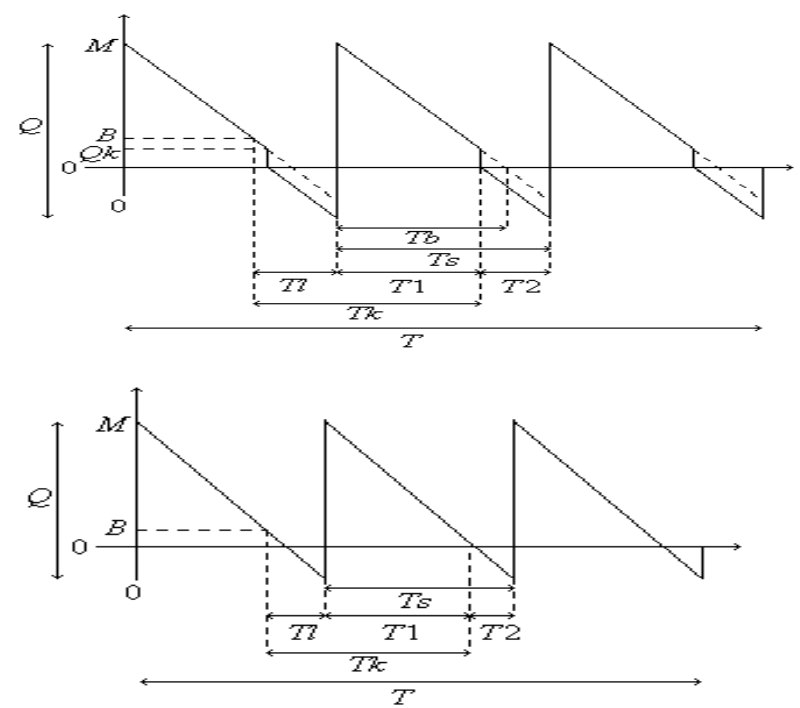

Gambar 3. Model persediaan dengan pertimbangan masa kadaluwarsa pada kasus backorder

\section{Model EOQ dengan Pertimbangan Masa Kada- luwarsa dan Unit Diskon}

Pada model dengan pertimbangan unit diskon, ada kalanya lebih baik bahan dibeli meskipun menjadi kadaluwarsa hanya untuk mendapatkan harga barang yang lebih murah. Hal ini perlu dilakukan dikarenakan besarnya biaya akibat kekurangan bahan.

Gambar 4 menunjukan model persediaan dengan memperhatikan kadaluwarsa, dan unit diskon pada kasus lost sales dan backorder. Berdasarkan Gambar 4, total biaya persediaan pada kasus lost-sales dapat dinyatakan sebagai berikut:

$T c_{i}=P 1_{i} Q \frac{1}{T s}-J(Q-D T s) \frac{1}{T s}+S \frac{1}{T s}+\frac{P 1_{i} H(2 Q-D T s)}{2}$

Pada kasus backorder total biaya persediaan yang dikeluarkan adalah:

$$
\begin{aligned}
T c_{i}= & P 1_{i} \frac{Q}{T s}-J\left(\frac{Q}{T s}-D\right)+\frac{S}{T s}+ \\
& \frac{P 1_{i} h}{2}\left(\frac{2 Q(T k-T l)}{T s}-D\left(2(T k-T l)-\frac{(T k-T l)^{2}}{T s}\right)\right)+ \\
& \frac{C b D}{2}\left(T s-2(T k-T l)+\frac{(T k-T l)^{2}}{T s}\right)
\end{aligned}
$$

dimana

$T s_{i}^{*}=$

$\sqrt{\frac{2\left(P_{i} Q-J Q+S+\frac{P_{i} H}{2}\left(2 Q(T k-T l)+D(T k-T l)^{2}\right)+\frac{C b . D}{2}(T k-T l)^{2}\right)}{C b D}}$
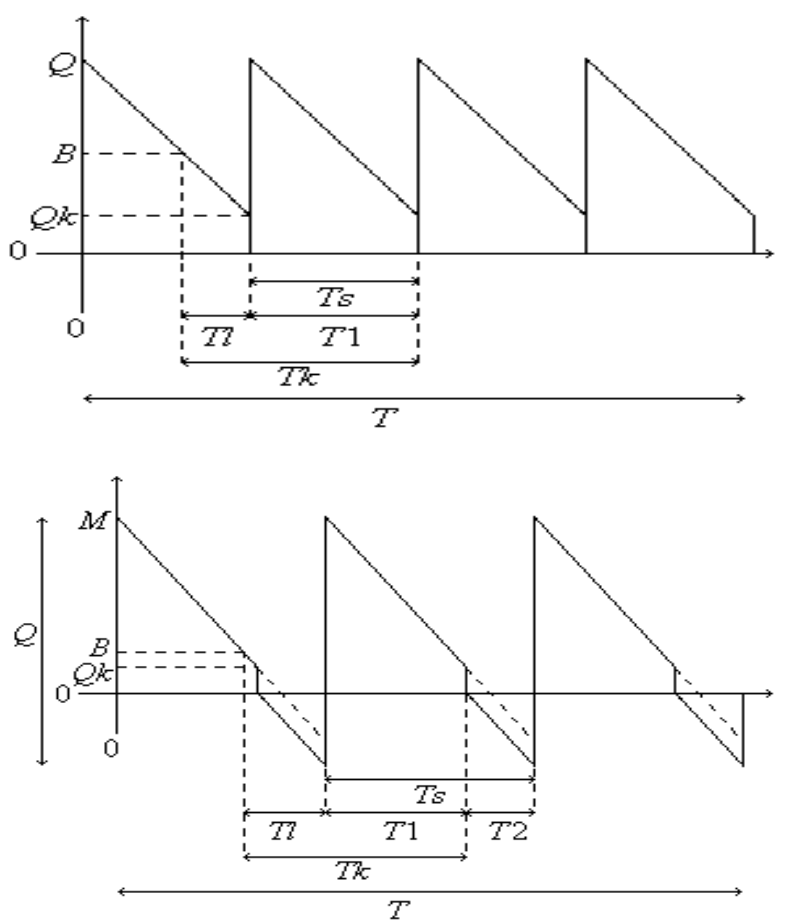

Gambar 4. Model persediaan dengan pertimbangan masa kadaluwarsa dan unit diskon dimana bahan dibeli melebihi kebutuhan pada kasus lost-sales (atas) dan backorder (bawah) 
Penyelesaian permasalahan persediaan persediaan dengan mempertimbangkan masa kadaluwarsa pada kasus lost-sales dapat dilakukan dengan langkahlangkah berikut ini (harga yang digunakan adalah $\left.P 1_{i}\right)$ :

1. Menghitung $T s_{i}^{*}$ dengan persamaan (2). Apabila $T s_{i}^{*}>T 1$, ubahlah $T s_{i}^{*}$ dengan $T 1$ dan hitung $Q^{*}$ dengan persamaan (3). Beberapa kondisi yang perlu diperhatikan pada $Q^{*}$ adalah jika:

a. $Q_{i}^{*}$ berada di bawah price-break, lanjut ke langkah 2.

b. $Q_{i}^{*}$ berada dalam interval price-break, hitunglah $T c_{i}^{*}$ dengan persamaan (1) dan lanjut ke langkah 3.

c. $Q_{i}^{*}$ berada di atas price-break, tidak ada solusi yang valid.

2. Menghitung $T s_{i}^{*}$ dengan persamaan (3) dimana $Q$ adalah batas bawah price-break, apabila $T s_{i}^{*}$ $>T 1$, ubahlah $T s_{i}^{*}$ dengan $T 1$, dan simpan batas bawah price-break sebagai $Q_{i}^{*}$, kemudian hitunglah $T c_{i}^{*}$ dengan persamaan (12).

3. Membandingkan nilai $T c_{i}{ }^{*}$ dengan $T c^{*}$, jika $T c_{i}^{*}<T c^{*}$, simpan $T c_{i}^{*}$ sebagai $T c^{*}$, simpan $T s_{i}^{*}$ sebagai $T s^{*}$, dan simpan $Q_{i}^{*}$ sebagai $Q^{*}$. Apabila belum semua price-break- $i$ telah dihitung solusinya, kembali ke langkah 1.

Penyelesaian pada kasus backorder dapat dilakukan dengan langkah sebagai berikut (harga yang digunakan adalah $P 1_{i}$ ):

1. Menghitung $T s_{i}{ }^{*}$ dengan persamaan (7) dan $T b$ dengan menggunakan persamaan (5) dan (6). Apabila $T b<=T 1$, lanjut ke langkah 2. Lainnya, lanjut ke langkah 4.

2. Menghitung $Q_{i}^{*}$ dengan persamaan (3). Jika $Q_{i}$ * berada dalam interval price-break, nilai $T c_{i}^{*}$ dan $M_{i}^{*}$ dihitung dengan persamaan (4) dan (5) kemudian lanjutkan ke langkah 5. Jika $Q_{i}^{*}$ berada di atas price-break, tidak ada solusi valid. Sedangkan bila $Q_{i}^{*}$ berada di bawah pricebreak, lanjut ke langkah 3.

3. Menghitung $T s_{i}{ }^{*}$ dengan persamaan (3) dimana $Q$ adalah batas bawah interval price-break. Menghitung $T b$ dengan menggunakan persamaan (5) \& (6). Apabila $T b<=T 1$, jadikan $Q$ sebagai $Q_{i}^{*}$ dan hitung nilai $T c_{i}^{*}$ dan $M_{i}^{*}$ dengan persamaan (4) dan (5) lalu lanjutkan ke langkah 5. Sebaliknya, apabila $T b>T 1$, lanjut ke langkah 5.

4. Menghitung $T s_{i}^{*}$ dengan persamaan (11). Apabila $T s_{i}^{*}<T 1$, maka $T s^{*}=T 1$. Hitung $Q_{i}^{*}$ dengan persamaan (3), apabila $Q_{i}^{*}$ berada dalam interval price-break, hitung nilai $T c_{i}^{*}$ dengan persamaan (10), dan $M_{i}^{*}$ dengan persamaan (5), lanjut ke langkah 6 . Jika $Q_{i}^{*}$ berada di atas price-break, tidak ada solusi valid, bila $Q_{i}{ }^{*}$ berada di bawah price-break, lanjut ke langkah 5.

5. Menghitung $T s_{i}^{*}$ dengan persamaan (14) dimana $Q$ adalah batas bawah interval price- break. Apabila $T s_{i}^{*}<T 1$, maka $T s^{*}=T 1$. Jadikan $Q$ sebagai $Q_{i}^{*}$, hitung nilai $T c_{i}^{*}$ dengan persamaan (13) dan $M_{i}^{*}$ dengan persamaan (5) dan (6).

6. Membandingkan nilai $T c_{i}^{*}$ dengan $T c^{*}$, jika $T c_{i}^{*}<T c^{*}$, simpan $T c_{i}^{*}$ sebagai $T c^{*}$, simpan $T s_{i}^{*}$ sebagai $T s^{*}$, dan simpan $Q_{i}^{*}$ sebagai $Q^{*}$. Apabila belum semua price-break $i$ telah dihitung solusinya, kembali ke langkah 1.

\section{EOQ Multi Item dengan Mempertimbangkan Masa Kadaluwarsa dan Unit Diskon}

Berikut ini adalah total biaya persediaan untuk model EOQ multi item (Djunaedi [2]):

$T c=\frac{s}{T s}+\sum_{j=1}^{n}\left(P 2_{j} D+\frac{D_{j} T s}{2} P 2_{j} H\right)$

dengan $t$ optimal sebesar:

$T s^{*}=\sqrt{\frac{2 S}{\sum_{j=1}^{n}\left(D_{j} P 2_{j} H\right)}}$

dimana $Q_{j}$ bernilai:

$Q_{j}=D_{j} T S$

Total biaya EOQ multi item for backorder adalah:

$$
\begin{aligned}
T c=\frac{s}{T s}+\sum_{j=1}^{n}( & P 2_{j} D_{j}+\frac{D_{j} T s\left(\frac{C b_{j}}{P 2_{j} H+C b_{j}}\right)^{2}}{2} P_{j} H+ \\
& \left.\frac{D_{j} T s\left(\frac{P_{j} H}{P 2_{j} H+C b_{j}}\right)^{2}}{2} C b_{j}\right)
\end{aligned}
$$

dan pada kasus backorder $M$ optimal bernilai:

$M_{j}{ }^{*}=Q_{j}{ }^{*} \frac{C b_{j}}{P 2_{j} H+C b_{j}}$

dan $T b$ bernilai:

$T b_{j}=T s \frac{M_{j}}{Q_{j}}$

dimana

$T s^{*}=\sqrt{\frac{2 S}{\sum_{j=1}^{n}\left(\frac{D_{j}{ }^{2} j^{H C b_{j}}}{P{ }^{2} j^{H+C b_{j}}}\right)}}$

Bilamana terdapat kadaluwarsa, kasus backorder akan lebih baik bila besarnya maksimum persediaan $(M)$ sebesar jumlah permintaan selama $T 1$ sehingga, total biaya persediaan menjadi:

$$
\begin{aligned}
T c_{k}= & \frac{s}{T s}+\sum_{j=1}^{n}\left(P_{j k} D+P_{j k} H D_{j} \frac{\left(T k_{j}-T l\right)^{2}}{2 T s}+\right. \\
& \left.\frac{C b_{j} D_{j}}{2}\left(T s-2\left(T k_{j}-T l\right)+\frac{\left(T k_{j}-T l\right)^{2}}{T s}\right)\right)
\end{aligned}
$$

dimana

$T s_{k}{ }^{*}=\sqrt{\frac{2\left(S+\sum_{j=1}^{n}\left(\frac{P_{j k} H D_{j}}{2}\left(T k_{j}-T l\right)^{2}+\frac{C b_{j} D_{j}}{2}\left(T k_{j}-T l\right)^{2}\right)\right)}{\sum_{j=1}^{n} C b_{j} D_{j}}}$ 
Apabila waktu kadaluwarsa tiap bahan berbeda, maka solusi dapat dihasilkan dengan simulasi. Sementara apabila masa kadaluwarsanya sama, maka solusi optimal dapat dihasilkan dengan model matematis.

Persediaan multi item dengan mempertimbangkan kadaluwarsa dan unit diskon pada kasus lost-sales dapat diselesaikan dengan langkah-langkah berikut ini:

1. Menghitung nilai $T s_{k}{ }^{*}$ dengan persamaan (16). Apabila $T s_{k}{ }^{*}>T 1$, ubah $T s_{k}{ }^{*}=T 1$.

2. Menghitung setiap $Q_{j k}{ }^{*}$ dengan persamaan (17) dan membandingkannya dengan interval pricebreak pada kombinasi price-break. Apabila semua $Q_{j k} *$ berada dalam price-break maka solusi valid, kemudian hitunglah $T c_{k}{ }^{*}$ dengan persamaan (15). Sebaliknya, jika $Q_{j k}{ }^{*}$ berada di luar price-break maka solusi yang dihasilkan tidak valid.

3. Membandingkan nilai $T c_{k}$ * dengan $T c^{*}$. Jika $T c_{k}{ }^{*}<T c^{*}$ maka simpanlah $T c_{k}{ }^{*}$ sebagai $T c^{*}, T s_{k}{ }^{*}$ sebagai $T s^{*}$, dan setiap $Q_{j k}{ }^{*}$ sebagai $Q_{j}^{*}$. Apabila belum semua kombinasi price-break dihitung solusinya, kembali ke langkah 1.

Penyelesaian pada kasus backorder dapat dilakukan dengan tahapan sebagai berikut:

1. Menghitung nilai $T s_{k}{ }^{*}$ dengan persamaan (21) dan $T b_{j}$ dengan persamaan (19), dan (20). Apabila semua $T b_{j}<=T 1$, lanjut ke langkah 2 . Lainnya, lanjut ke langkah 3.

2. Hitunglah setiap $Q_{j k} *$ dengan persamaan (17) dan membandingkannya dengan interval pricebreak pada kombinasi price-break. Apabila semua $Q_{j k}{ }^{*}$ berada dalam price-break maka solusi valid. Kemudian itunglah $T c_{k}{ }^{*}$ dan $M_{j k}$ * dengan persamaan (18) dan persamaan (19). Sedangkan jika $Q_{j k} *$ berada di luar price-break maka solusi tidak valid dan lanjut ke langkah 4.

3. Menghitung nilai $T_{s k}{ }^{*}$ dengan persamaan (23). Apabila $T s_{k}{ }^{*}<T 1$, maka tetapkan $T s_{k}{ }^{*}=T 1$. Hitunglah setiap $Q_{j k} *$ dengan persamaan (17) dan membandingkannya dengan interval pricebreak pada kombinasi price-break. Apabila semua $Q_{j k}{ }^{*}$ berada dalam price-break maka solusi valid, hitunglah $T c_{k}{ }^{*}$ dengan persamaan (22) dan $M_{j k}{ }^{*}$ dengan persamaan (19), sebaliknya, solusi tidak valid.

4. Membandingkan nilai $T c_{k}^{*}$ dengan $T c^{*}$, jika $T c_{k}^{*}<T c^{*}$, simpanlah $T c_{k}^{*}$ sebagai $T c^{*}, T s_{k}^{*}$ sebagai $T s^{*}$, setiap $Q_{j k}{ }^{*}$ sebagai $Q_{j}^{*}$, dan setiap $M_{j k}$ * sebagai $M_{j}^{*}$. Kembali ke langkah 1 jika belum semua kombinasi price-break dihitung solusinya.

Beberapa hal yang menjadi kelemahan pada langkah-langkah penyelesaian ini adalah tidak dapat terakomodasinya faktor diskon dan adanya asumsi masa kadaluwarsa yang sama untuk semua jenis bahan. Penyelesaian persediaan dengan kondisi setiap bahan memiliki masa kadaluwarsa yang berbeda ataupun diskon lebih diperhitungkan akan lebih mudah dan efisien diselesaikan dengan menggunakan simulasi.

\section{EOQ Multi Item dengan Mempertimbangkan Masa Kadaluwarsa dan Unit Diskon pada Non-Konstan Demand}

Pada penelitian ini pengembangan model EOQ yang mempertimbangkan masa kadaluwarsa dan unit diskon untuk kondisi multi item diselesaikan melalui simulasi dengan menggunakan prinsip periodic review. Periodic review merupakan salah satu metode pemenuhan persediaan bahan baku yang dapat digunakan untuk permintaan yang bersifat probabilistik. Konsep periodic review ini bekerja dengan melakukan pemeriksaan persediaan bahan baku tiap akhir periode dan memutuskan berapa jumlah bahan baku yang harus dibeli agar dapat memenuhi permintaan. Besarnya maksimum persediaan di gudang harus dapat memenuhi permintaan selama periode pengecekan dan leadtime pemesanan.

Simulasi dilakukan dengan menentukan tingkat persediaan tiap siklus pemesanan dan menghitung biaya per siklus selama siklus, sebelum dikonversi menjadi biaya tahunan. Biaya siklus memiliki persamaan yang berbeda-beda bergantung pada kondisi siklus tersebut dalam simulasi. Simulasi dilakukan dengan menggunakan algoritma genetika.

Berikut perhitungan biaya per siklus untuk kasus lost-sales berdasarkan kondisi siklus:

$$
\begin{gathered}
\left(T s<T 1 ; Q e_{t-1}>0 ; D_{t} \frac{T 1-T s}{T s} \geq Q e_{t-1} ; Q e_{t} \geq 0\right) . \\
C c_{j t}=Q_{j t} P_{i j}+P_{i j} H \frac{2\left(Q e_{j(t-1)}+Q_{j t}\right)-D_{j t}}{2} T s \\
\left.T s<T 1 ; Q e_{t-1}>0 ; D_{t} \frac{T 1-T s}{T s}<Q e_{t-1} ; Q e_{t} \geq 0\right) . \\
C c_{j t}=Q_{j t} P_{i j}-\left(Q e_{j(t-1)}-D_{j t} \frac{T 1_{j}-T s}{T s}\right) J_{j}+ \\
P_{i j} H\left(\frac{2 Q e_{j(t-1)}+2 Q_{j t}-D_{j t} \frac{T 1_{j}-T s}{T s}}{2}\left(T 1_{j}-T s\right)+\right. \\
\left.\frac{2 Q_{j t}-D_{j t} \frac{2 T s-T 1_{j}}{T s}}{2}\left(2 T s-T 1_{j}\right)\right)
\end{gathered}
$$

$\left(T s<T 1 ; Q e_{t-1}>0 ; D_{t} \frac{T 1-T s}{T s} \geq Q e_{t-1} ; Q e_{t}<0\right)$.

$C c_{j t}=Q_{j t} P_{i j}+P_{i j} H \frac{\left(Q e_{j(t-1)}+Q_{j t}\right)^{2}}{2 D_{j t}} T s+$

$C l_{j}\left(D_{j t}-Q e_{j(t-1)}-Q_{j t}\right)$

$\left(T s<T 1 ; Q e_{t-1}>0 ; D_{t} \frac{T 1-T s}{T s}<Q e_{t-1} ; Q e_{t}<0\right)$.

$$
\begin{aligned}
C c_{j t}= & Q_{j t} P_{i j}-\left(Q e_{j(t-1)}-D_{j t} \frac{T 1_{j}-T s}{T s}\right) J_{j}+ \\
& P_{i j} H\left(\frac{2 Q e_{j(t-1)}+2 Q_{j t}-D_{j t} \frac{T_{j} j}{T s}}{2}\left(T 1_{j}-T s\right)+\frac{Q_{j t^{2}}{ }^{2}}{2 D_{j t}} T s\right)+ \\
& C_{l j}\left(D_{j t} \frac{2 T s-T 1_{j}}{T s}-Q_{j t}\right)
\end{aligned}
$$




$$
\begin{aligned}
& \left(T s<T 1 ; Q e_{t-1} \leq 0 ; Q e_{t} \geq 0\right) \\
& C c_{j t}=Q_{j t} P_{i j}+P_{i j} H \frac{2 Q_{j t}-D_{j t}}{2} T s \\
& \left(T s<T 1 ; Q e_{t-1} \leq 0 ; Q e_{t}<0\right) . \\
& C c_{j t}=Q_{j t} P_{i j}+P_{i j} H \frac{Q_{j t}{ }^{2}}{2 D_{j t}} T s+C l_{j}\left(D_{j t}-Q_{j t}\right) \\
& \left(T s \geq T 1 ; D_{t} \geq Q_{t}\right) . \\
& C c_{j t}=Q_{j t} P_{i j}+P_{i j} H \frac{Q_{j t}{ }^{2}}{2 D_{j t}} T s+C l_{j}\left(D_{j t}-Q_{j t}\right) \\
& \left(T s \geq T 1 ; D_{t}<Q_{t}\right) . \\
& C c_{j t}=Q_{j t} P_{i j}-\left(Q_{j t}-D_{j t} \frac{T 1_{j}}{T s}\right) J_{j}+P_{i j} H \frac{2 Q_{j t}-D_{j t} \frac{T 1_{j}}{T s}}{2} T 1_{j}+ \\
& \quad C l_{j} D_{j t} \frac{T s-T 1_{j}}{T s}
\end{aligned}
$$

Persamaan untuk kasus backorder berdasarkan kondisi siklus adalah:

$$
\begin{gathered}
\left(T s<T 1 ; Q e_{t-1}>0 ; D_{t} \frac{T 1-T s}{T s} \geq Q e_{t-1} ; Q e_{t} \geq 0\right) . \\
C c_{j t}=Q_{j t} P_{i j}+P_{i j} H \frac{2\left(Q e_{j(t-1)}+Q_{j t}\right)-D_{j t}}{2} T s \\
\left(T s<T 1 ; Q e_{t-1}>0 ; D_{t} \frac{T 1-T s}{T s}<Q e_{t-1} ; Q e_{t} \geq 0\right) . \\
C c_{j t}=Q_{j t} P_{i j}-\left(Q e_{j(t-1)}-D_{j t} \frac{T 1_{j}-T s}{T s}\right) J_{j}+ \\
P_{i j} H\left(\frac{2 Q e_{j(t-1)+2 Q_{j t}-D_{j t} \frac{T 1_{j}-T s}{T s}}^{2}\left(T 1_{j}-T s\right)+}{2}\right) \\
\left.\frac{2 Q_{j t}-D_{j t} \frac{2 T s-T 1_{j}}{T s}}{2}\left(2 T s-T 1_{j}\right)\right)
\end{gathered}
$$

$$
\begin{aligned}
(T s< & \left.T 1 ; Q e_{t-1}>0 ; D_{t} \frac{T 1-T s}{T s} \geq Q e_{t-1} ; Q e_{t}<0\right) . \\
C c_{j t}= & Q_{j t} P_{i j}+P_{i j} H \frac{\left(Q e_{j(t-1)}+Q_{j t}\right)^{2}}{2 D_{j t}} T s+ \\
& C b_{j} \frac{\left(Q e_{j(t-1)}+Q_{j t}-D_{j t}\right)^{2}}{2 D_{j t}} T s
\end{aligned}
$$

$$
\begin{aligned}
(T s< & \left.T 1 ; Q e_{t-1}>0 ; D_{t} \frac{T 1-T s}{T s}<Q e_{t-1} ; Q e_{t}<0\right) . \\
C c_{j t}= & Q_{j t} P_{i j}+P_{i j} H \frac{\left(Q e_{j(t-1)}+Q_{j t}\right)^{2}}{2 D_{j t}} T s+ \\
& C b_{j} \frac{\left(D_{j t} \frac{2 T s-T 1_{j}}{T s}-Q_{j t}\right)^{2}}{2 D_{j t}} T s
\end{aligned}
$$

$\left(T s<T 1 ; Q e_{t-1} \leq 0 ; Q e_{t} \geq 0\right)$

$C c_{j t}=Q_{j t} P_{i j}+P_{i j} H \frac{2\left(Q e_{j(t-1)}+Q_{j t}\right)-D_{j t}}{2} T s$

$\left(T s<T 1 ; Q e_{t-1} \leq 0 ; Q e_{t}<0\right)$.

$$
\begin{gathered}
C c_{j t}=Q_{j t} P_{i j}+P_{i j} H \frac{\left(Q e_{j(t-1)}+Q_{j t}\right)^{2}}{2 D_{j t}} T s+ \\
C b_{j} \frac{\left(Q e_{j(t-1)}+Q_{j t}-D_{j t}\right)^{2}}{2 D_{j t}} T s
\end{gathered}
$$

$\left(T s<T 1 Q_{t}+Q e_{t-1}<0\right)$

$C c_{j t}=Q_{j t} P_{i j}+C b_{j} \frac{-2 Q e_{j(t-1)}-Q_{j t}+D_{j t}}{2} T s$

$\left(T s \geq T 1 ; D_{t} \geq Q_{t}\right)$.

$C c_{j t}=Q_{j t} P_{i j}+P_{i j} H \frac{\left(Q e_{j(t-1)}+Q_{j t}\right)^{2}}{2 D_{j t}} T s+$

$C b_{j} \frac{\left(Q e_{j(t-1)}+Q_{j t}-D_{j t}\right)^{2}}{2 D_{j t}} T S$
$\left(T s \geq T 1 ; D_{t}<Q_{t}\right)$.

$C c_{j t}=Q_{j t} P_{i j}-\left(Q e_{j(t-1)}+Q_{j t}-D_{j t} \frac{T 1_{j}}{T s}\right) J_{j}+$

$P_{i j} H \frac{2\left(Q e_{j(t-1)}+Q_{j t}\right)-D_{j t} \frac{T 1_{j}}{T s}}{2} T 1_{j}+C b_{j} \frac{D_{j t}\left(T s-T 1_{j}\right)^{2}}{2 t}$

$\left(T s \geq T 1 ; Q_{t}+Q e_{t-1}<0\right)$.

$C c_{j t}=Q_{j t} P_{i j}+C b_{j} \frac{-2 Q e_{j(t-1)}-Q_{j t}+D_{j t}}{2} T s$

Rumus biaya persediaan tahunan adalah:

$T C=\frac{1}{t} \sum_{j=1}^{n} \frac{1}{o} \sum_{t=1}^{o} C c_{j t}$

\section{Hasil dan Pembahasan}

Skenario yang dilakukan pada simulasi ini adalah jenis item yang dipesan sebanyak tiga, permintaan didapatkan dengan membangkitkan bilangan random yang berdistribusi normal, dan leadtime pemesanan sebesar 26 hari. Semua komponen biaya, diskon serta harga jual barang kadaluwarsa untuk tiap jenis item berbeda-beda, kecuali biaya pemesanan. Detail data yang digunakan pada simulasi ini dapat dilihat pada Tabel 1 dan Tabel 2. Pada tiap kasus, simulasi dijalankan untuk 1000 siklus.

Hasil simulasi untuk kasus lost-sales adalah lama selang waktu siklus sebesar 48,75 hari dengan maksimum persediaan untuk item A,B, dan C sebesar 108,5, 181,1, dan 292,3. Ekspektasi total biaya persediaan untuk kasus lost-sales adalah 35.209.630. Pada kasus backorder selang waktu siklus sebesar 101 hari dengan maksimum persediaan item A, B, dan C adalah 111,4, 185,15, 286,6. Ekspektasi total biaya persediaan pada kasus backorder adalah 30.591.066.

Tabel 1. Data skenario simulasi

\begin{tabular}{ccccccccr}
\hline $\mathrm{X} 1$ & $\mathrm{X} 2$ & $\mathrm{X} 3$ & $\mathrm{X} 4$ & $\mathrm{X} 5$ & $\mathrm{X} 6$ & $\mathrm{X} 7$ & $\mathrm{X} 8$ & $\mathrm{X} 9$ \\
\hline $\mathrm{A}$ & 500 & 50 & 92 & 15000 & 5000 & & & 5000 \\
$\mathrm{~B}$ & 800 & 80 & 100 & 12000 & 4000 & 26 & $5 \%$ & 4000 \\
$\mathrm{C}$ & 1250 & 125 & 97 & 21000 & 7000 & & & 7000 \\
\hline
\end{tabular}

$\mathrm{X} 1$ : item

$\mathrm{X} 2$ : mean demand tahunan

$\mathrm{X} 3$ : stdev demand tahunan

$\mathrm{X} 4$ : waktu kadaluwarsa (hari)

X5 : biaya lost-sale (per item)

$\mathrm{X} 6$ : biaya backorder (per item per tahun)

$\mathrm{X} 7$ : lead time (hari)

$\mathrm{X} 8$ : holding rate (tahun)

X9 : harga jual kadaluwarsa(per item)

Ordering cost* untuk setiap item 100000

Tabel 2. Data diskon tiap item

\begin{tabular}{ccr}
\hline Item & $\begin{array}{c}\text { Interval price } \\
\text { break }\end{array}$ & $\begin{array}{c}\text { Harga beli } \\
\text { (per item) }\end{array}$ \\
\hline $\mathrm{A}$ & $<=115$ & 11500 \\
& $>115$ & 10000 \\
$\mathrm{~B}$ & $<=175$ & 9500 \\
& $>175$ & 8000 \\
$\mathrm{C}$ & $<=250$ & 15000 \\
& $>250$ & 14000 \\
\hline
\end{tabular}




\section{Analisa Sensitivitas Kasus Lost-sales}

Analisa sensitivitas pada kasus lost-sales dilakukan dengan melakukan perubahan biaya simpan, biaya lost-sales, harga jual kadaluwarsa, dan harga jual. Analisa sensitivitas dijalankan untuk melihat seberapa besar pengaruh perubahan parameter terhadap total biaya persediaan. Hasil simulasi menunjukkan perubahan biaya simpan hingga $40 \%$ tidak memberikan pengaruh terhadap variabel keputusan selang waktu siklus (Ts) namun berpengaruh terhadap besarnya maksimum persediaan $(M)$.

Perubahan harga jual bahan kadaluwarsa sebesar $20 \%$ maupun $40 \%$ menyebabkan perubahan pada keputusan selang waktu siklus pemesanan $(T s)$, terutama saat harga jual naik hingga 40\%. Perubahan harga jual kadaluwarsa juga menyebabkan perubahan pada keputusan besarnya maksimum persediaan $\left(M_{j}\right)$, dimana maksimum persediaan tiap item semakin besar seiring meningkatnya harga jual bahan kadaluwarsa. Hal ini disebabkan dengan semakin naiknya harga jual bahan kadaluwarsa mengurangi kerugian akibat kadaluwarsa. Oleh karenanya pada kondisi ini bahan dapat dibeli lebih banyak untuk mengurangi kemungkinan lost-sales meskipun kemungkinan kadaluwarsa meningkat. Peningkatan jumlah barang yang dipesan berakibat pada naiknya jumlah persediaan dan kadaluwarsa, namun menurunkan lost-sales. Perubahan biaya lost-sales sebesar $20 \%$ maupun $40 \%$ menyebabkan perubahan pada variabel keputusan. Semakin besar biaya lost-sales maka semakin kecil selang waktu siklus $(T s)$. Maksimum persediaan $\left(M_{j}\right)$ semakin besar seiring dengan semakin besarnya biaya lostsales.

\section{Analisa Sensitivitas Kasus Backorder}

Perubahan biaya simpan hingga $40 \%$ tidak memberikan pengaruh terhadap variabel keputusan yang diambil untuk mendapatkan total biaya persediaan minimum. Hal ini dapat dilihat dari besarnya selang waktu siklus dan persediaan maksimum yang tidak membentuk pola seiring berubahnya biaya simpan.

Perubahan harga jual bahan kadaluwarsa sebesar $20 \%$ maupun $40 \%$ juga tidak menyebabkan perubahan pada variabel keputusan selang waktu siklus pemesanan namun menyebabkan perubahan pada maksimum persediaan $\left(M_{j}\right)$. Nilai $M_{j}$ semakin besar seiring meningkatnya harga jual bahan kadaluwarsa. Hal ini disebabkan semakin naiknya harga jual bahan kadaluwarsa mengurangi kerugian akibat kadaluwarsa. Peningkatan pemesanan berakibat pada naiknya jumlah persediaan dan kadaluwarsa, namun menurunkan backorder.
Perubahan biaya backorder menyebabkan perubahan pada variabel keputusan. Semakin besar biaya backorder menyebabkan semakin kecilnya selang waktu siklus (Ts) dan semakin besarnya maksimum persediaan $\left(M_{j}\right)$. Hal ini disebabkan semakin naiknya biaya backorder menyebabkan backorder lebih baik jika semakin sedikit. Semakin besar waktu kadaluwarsa, waktu siklus optimal akan semakin besar hingga sampai pada titik optimal.

\section{Simpulan}

Pada kasus backorder untuk single item didapatkan bahwa besar maksimum persediaan akan menghasilkan solusi yang lebih baik jika disesuaikan dengan jumlah permintaan selama waktu efektif dari bahan datang hingga waktu kadaluwarsa. Pengembangan model persediaan multi item dengan mempertimbangkan model untuk kasus lost-sales maksimum persediaan dipengaruhi oleh biaya simpan, harga jual bahan kadaluwarsa, dan biaya lostsales. Selang waktu siklus untuk kasus lost-sales hanya dipengaruhi oleh harga jual bahan kadaluwarsa dan biaya lost-sales. Pada kasus backorder persediaan multi item ini besarnya persediaan maksimum dipengaruhi harga jual bahan kadaluwarsa dan biaya backorder. Selang waktu siklus hanya dipengaruhi oleh biaya backorder.

\section{Daftar Pustaka}

1. Bramorski T., Determining Discounts for Perishable Inventory, Journal of Business \& Economics Research, 6(1), 2008, pp. 51-58.

2. Djunaidi, M., Nandiroh, S., dan Marzuki, I. O., Pengaruh Perencanaan Pembelian Bahan Baku dengan Model EOQ untuk Multi Item dengan All Unit Discount, Jurnal Ilmiah Teknik Industri, 4(2), 2005, pp. 83-89.

3. Elsayed, A., dan Boucher, T. O., Analysis and Control of Production Systems, 2nd. Edition, Englewood Cliffs: Prentice Hall, 1994.

4. Hsu, P. H., Optimal Ordering Policy for Fast Deteriorating Items, African Journal of Business Management, 6(30), 2012, pp. 8837-8852.

5. Hsu, P. H., Wee H. M., and Teng H. M., Optimal Lot Sizing for Deteriorating Items with Expiration Date, Journal of Information \& Optimization Sciences, 27(2), 2006, pp. 271-286.

6. Indrianti, N., Ming. T., dan Toha, I. S., Model Perencanaan Kebutuhan Bahan dengan Mempertimbangkan Waktu Kadaluwarsa Bahan. Jurnal Media Teknik, 2, 2001, pp. 60-65

7. Limansyah, T., dan Lesmono, D., Model Persediaan Multi Item dengan Mempertimbangkan Faktor Kadaluwarsa dan Faktor All Unit 
Discount, Jurnal Teknik Industri, 13(2), 2011, pp. 87-94.

8. Muckstadt, J. A., and Sapra, A., Principles of Inventory Management: When You are Down to Four, Order More, New York: Springer, 2009.

9. Panda, S., Saha, S., and Basu, M., An EOQ Model for Perishable Products with Discounted Selling Price and Stock Dependent Demand, New York: Springer, 2008.
10. Prasetyo, H., Nugroho, M. T., dan Pujiarti, A. Pengembangan Model Persediaan Bahan Baku dengan Mempertimbangkan Waktu Kadaluwarsa dan Faktor Unit Diskon, Jurnal Ilmiah Teknik Industri, 4(3), 2006, pp. 108-115.

11. Russel, R. S., and Taylor, B. W., Operations Management: Focusing on Quality and Competitiveness in a Global Environment $5^{\text {th }}$ Edition, New Jersey: Prentice Hall, 2006. 